\title{
IMPACTS OF AGGREGATOR BUSINESS ON FARMERS' INCOME
}

\author{
Siti Jahroh* )1, Janita S. Meliala**) \\ *)School of Business, IPB University \\ Jl. Raya Pajajaran Bogor 16151, Indonesia \\ ${ }^{* *}$ Business Creation Program, Management Department, BINUS Business School Undergraduate Program, \\ Bina Nusantara University \\ Jl. Kebon Jeruk Raya No.27 Kebon Jeruk, Jakarta 11480, Indonesia
}

\begin{abstract}
Agricultural produces pass a long journey from the farms up to the end consumers. With the advancement of information technology, aggregator businesses have emerged to shorten the long distribution chain. Therefore, farmers as producers can access information both on prices received by consumers and the characteristics of products demanded by consumers. This study aims to (1) explain the distribution chain mechanism through the aggregator business, and (2) analyze the impact on farmers who join the aggregator business distribution chain. There were 12 aggregator businesses and 36 farmers were interviewed as respondents from February to April 2019 using the purposive sampling method. The analysis was conducted using a descriptive approach and a paired sample t-test was carried out to see the impact of the existence of an aggregator on farmers. The results showed that the distribution chain through the aggregator business was shorter compared to the conventional one in which farmers had specific contracts or agreements with the aggregator business. The impact on farmers who join the aggregator business distribution chain is receiving higher prices, leading to increase farmers' income, transparency in prices where farmers know the selling prices at the consumer level, and farmers know consumer preferences for the products. It is expected that farmers will be able to produce better agricultural produces according to consumer preferences as well as to increase farmers' income.
\end{abstract}

Keywords: distribution chain, price, product preferences, transparency

\begin{abstract}
Abstrak: Produk hasil pertanian melewati perjalanan yang panjang dari petani hingga konsumen akhir. Dengan kemajuan teknologi informasi, bisnis agregator bermunculan untuk memperpendek rantai distribusi yang panjang tersebut. Dengan demikian petani sebagai produsen dapat mengakses informasi baik harga yang diterima konsumen maupun karakteristik produk yang diminta konsumen. Penelitian ini bertujuan untuk (1) menjelaskan mekanisme rantai distribusi melalui bisnis agregator, dan (2) menganalisis dampaknya terhadap petani yang bergabung dalam rantai distribusi bisnis aggregator. Terdapat 12 pelaku usaha agregator dan 36 petani yang diwawancarai sebagai responden pada bulan Februari hingga April 2019 dengan metode purposive sampling. Analisis dilakukan dengan pendekatan deskriptif dan dilakukan paired sample t-test untuk melihat dampak dari keberadaan agregator bagi petani. Hasil penelitian menunjukkan bahwa rantai distribusi melalui usaha agregator lebih pendek dibandingkan dengan konvensional dimana petani memiliki kontrak atau perjanjian khusus dengan usaha agregator. Dampak bagi petani yang tergabung dalam rantai distribusi usaha agregator adalah menerima harga yang lebih tinggi sehingga pendapatan petani meningkat, transparansi harga dimana petani mengetahui harga jual di tingkat konsumen, dan petani mengetahui preferensi konsumen terhadap produk tersebut. Diharapkan petani mampu menghasilkan hasil pertanian yang lebih baik sesuai preferensi konsumen serta dapat meningkatkan pendapatan petani.
\end{abstract}

Kata kunci: rantai distribusi, harga, preferensi produk, transparansi

\footnotetext{
${ }^{1}$ Corresponding author:

Email: sitijahroh@gmail.com
} 


\section{INTRODUCTION}

The rapid development of information technology (IT) is driving changes in people's behavior, and increasing needs to encourage the creation of business opportunities and new jobs. Changes and new business opportunities are driven by developments in the use of the internet that are realized by business people to utilize the internet in the business process. Indonesian Internet Service Providers Association revealed that internet users in Indonesia showed a positive trend, even in 2017 internet users in Indonesia had reached 143.26 million people. The internet has brought changes in electronic information exchanges to business strategy applications, marketing, sales, to customer service, as well as supporting global communication and cooperation between employees, consumers, sellers, and other business partners. Business opportunities offered in the era of advancement in information technology, especially the internet, include online marketing, online buying and selling business, financial technology, databased storage, and on-demand services that arise around us such as online transportation services.

The development of information technology has also become an opportunity for the development of the agricultural sector. Shaik et al. (2004) revealed that the benefits of IT that can support development in the agricultural sector related to ease of access services in the market. Moreover, the development of agricultural products is still faced with various kinds of problems, including obstacles in the process of trading in agricultural products (Santoso and Darwanto, 2015). The main problem in the process of trading agricultural products is the inefficiency of the distribution process of agricultural products from producers to consumers. The distribution of agricultural products must meet the adequate quantity, timeliness, and affordability in terms of prices received by consumers (Nurchayati, 2014).

The high demand for horticultural commodities has led to a long distribution network starting from the level of farmers, intermediary traders, to mobile/retail traders who sell directly to end consumers. On the other hand, horticultural products have perishable characteristics. FAO (2012) concluded that in developing countries vegetable products and perishable fruits suffer a lot of food loss in the post-harvest stage and the process of product distribution to consumers. Therefore, special handling of these commodities is needed as well as the shortest possible marketing channels, so that the processing time of horticultural commodities distribution from farmers/producers can quickly reach consumers.

The unfair advantage for horticultural product farmers is also a reflection of the inefficiency of agricultural products. The biggest profit margins are obtained by intermediary traders, while the greatest business risks are accepted by farmers/producers, especially those that are small-scale businesses and are unable to conduct their distribution businesses (Santoso and Darwanto, 2015). Some gaps in the prices of vegetable products at the farm level and the retail level are presented in Table 1. The magnitude of the price margin from producers to consumers through an average of more than $50 \%$ compared to prices received by producers. The distribution of agricultural products in Indonesia is still weak when seen from the marketing channel of agricultural commodities which has a long enough chain. The supply chain of agricultural products is still very fragmented with a large number of intermediaries. The importance of agricultural marketing policies to ensure fair returns to farmers (Nayak, 2016).

Table 1. Prices for some vegetables at the farmer and consumer level

\begin{tabular}{lccc}
\hline \multirow{2}{*}{\multicolumn{1}{c}{ Vegetables }} & \multicolumn{3}{c}{ Year } \\
\cline { 2 - 4 } & 2014 & 2015 & 2016 \\
\hline Kale & & & \\
Farm gate price (Rp/kg) & 3848.6 & 4093.5 & 4142.5 \\
Consumer price (Rp/kg) & 7761 & 6796 & 7161 \\
Margin (\%) & $101 \%$ & $66 \%$ & $73 \%$ \\
Tomato & & & \\
Farm gate price (Rp/kg) & 7061.7 & 7909.8 & 8583.2 \\
Consumer price (Rp/kg) & 12553.0 & 10808.0 & 11467.0 \\
Margin (\%) & $78 \%$ & $37 \%$ & $34 \%$ \\
Spinach & & & \\
Farm gate price (Rp/kg) & 4938.3 & 5213.3 & 5346.6 \\
Consumer price (Rp/kg) & 6612 & 7994 & 8562 \\
Margin (\%) & $34 \%$ & $53 \%$ & $60 \%$ \\
Red Chili & \multicolumn{3}{c}{} \\
Farm gate price (Rp/kg) & 19237.2 & 20977.4 & 21946.5 \\
Consumer price (Rp/kg) & 44519.0 & 44206.0 & 44648.0 \\
Margin (\%) & $131 \%$ & $111 \%$ & $103 \%$ \\
Shallot & & & \\
Farm gate price (Rp/kg) & 15591.5 & 16025.4 & 18677.6 \\
Consumer price (Rp/kg) & 26511.0 & 24658.0 & 30753.0 \\
Margin (\%) & $70 \%$ & $54 \%$ & $65 \%$ \\
\hline
\end{tabular}


Mejía and García-Díaz (2018) revealed that in the long run intermediaries can reduce the level of profit of producers/farmers. Intermediaries are often considered to reduce the efficiency of the distribution process of agricultural products by reducing prices at the producer level (Ranjan, 2017; Tapsavi, 2009). Intermediaries only increase personal profit without increasing the added value of the product through the benefits of limited market information owned by farmers as producers (Shankar et al. 2017).

On the other hand, food product aggregation is an important concept and function in local and regional food systems (Dillemuth and Hodgson, 2016). Aggregation refers to bringing together products from various sources to create a bigger and more consistent supply to meet consumer demand. This requires coordinating product sources from different producers to build reliable supply chains for different end markets such as restaurants and other foodservice providers, grocery stores, or wholesalers and institutions (for example, schools, hospitals, company cafeterias).

Aggregate means the total obtained by adding shared items. One can define aggregation as uniting in a coherent collection of different sources of information (Moghaddan and Moballegh, 2007). Lembong (2016) defined aggregators as companies or service providers that help accommodate a variety of products from sellers, and make these products available in a place that is easily found by potential customers.

Aggregators are collectors and intermediaries (Tapsavi, 2009). But the concept to be built is how an intermediary business model plays a role in creating profits for farmers and staying actively connected with this marketing intermediary. Nowadays, there are aggregators as modern actors who take advantage of digital technology. Digital technology also has the potential to offer consumers' greater transparency regarding how their food is produced (Nikola et al. 2019).

The presence of this modern actor can improve the welfare of farmers by increasing the selling price at the farmer level because of the transparency by utilizing information and communication technology (ICT) which is currently developing rapidly. The increase in farmer prices will lead to an increase in farmers' income. In addition, through the ICT, farmers would be able to access the information of the market and customers.
Research on platforms in the agricultural sector is currently still limited to analyzing consumer behavior, such as that conducted by Fikri et al. (2019) regarding online repurchase intention of vegetables/fruits. Therefore, this study was conducted to focus on the farmer (supplier) side where the existence of an online aggregator (platform in agriculture) would have a positive impact on farmers through the farmer selling price approach with different test methods. So the objectives of this paper are to (1) explain the mechanism of the distribution chain through business aggregators, and (2) analyze the impact of selling price on farmers who join the aggregator business distribution chain. The hypothesis is that the price received by farmers from the aggregator would be higher than the price received from the non-aggregator.

\section{METHODS}

This research was conducted from February to April 2019. To describe the distribution chain through business collectors carried out through a descriptive analysis approach. The object of this study is a company that operates as an aggregator of agricultural products. Table 2 is the data of 12 online agricultural commodity aggregators taken based on purposive sampling with aggregator criteria that enter the digital farming community.

The data used in this study include primary and secondary data. Primary data in this study were obtained through in-depth interviews and surveys. Secondary data include data that have been published, both by the company itself and other official institutions. The instrument used to obtain data was a questionnaire.

Furthermore, to analyze the impact of the existence of an aggregator, it was carried out by interviewing farmer partner aggregators whose data were obtained from the companies mentioned in Table 2. There are 33 farmer data available, but only 15 farmers sell vegetable products. Based on the hypothesis that the price received by farmers from the aggregator is higher than the price received from the non-aggregator so the method that chosen in this research is paired t-test analysis to see if there is a difference in the selling price of the aggregator compared to the non-aggregator. This method was chosen because the sample is the same but with different treatments. 
Table 2. Online-based aggregators in agriculture

\begin{tabular}{|c|c|}
\hline Name of Company & Website \\
\hline 8Villages & www.8Villages.com \\
\hline $\begin{array}{l}\text { PT Mandala Agro Persada } \\
\text { Nusantara }\end{array}$ & www.sayours.co.id \\
\hline $\begin{array}{l}\text { PT Insan Agritama } \\
\text { Teknologi }\end{array}$ & www.inagri.asia \\
\hline Pak Tani Digital & www.paktanidigital.com \\
\hline Kecipir & www.kecipir.com \\
\hline Sikumis & www.sikumis.com \\
\hline Sayurbox & www.sayurbox.com \\
\hline KORPRI Jawa Tengah & www.regopantes.com \\
\hline Etanee & www.etanee.co.id \\
\hline iGrow & www.igrow.asia \\
\hline Tanihub & www.tanihub.com \\
\hline Kedai Sayur & www.kedaisayur.com \\
\hline
\end{tabular}

- Agricultural trade inefficiency

- New tend: value chain disintermediation

- New tren: market alternatives

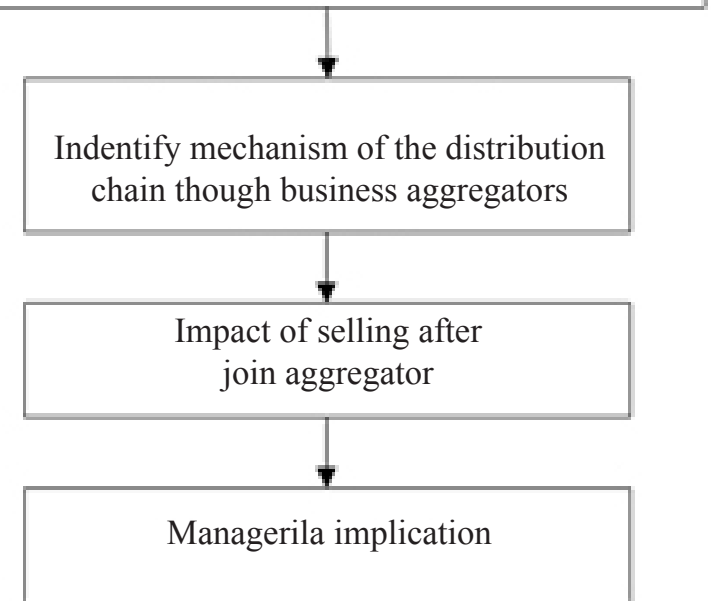

Figure 1. Research framework

The framework in the research can be seen in Figure 1. The first stage is the phenomena of agricultural trade inefficiency, value chain disintermediation, and market alternatives as to the background in conducting this research. The second stage is the identification of mechanisms in the distribution chain through business aggregators. The third stage is the impact of selling after joining the aggregator. Finally, the fourth stage is the managerial implications of this research.

\section{RESULTS}

\section{Overview of Aggregator Business Activity}

In general, the aggregator has the core activity of marketing agricultural products, focusing on the process of distribution and marketing of agricultural products. Marketing is done through a website or application. Through applications and websites, aggregators provide openness or access to farmers to find out market information. Larson (2014) showed that modern marketing would be able to increase profits for farmers and even small farmers.

Some aggregators carry out agricultural processing activities such as Sayurbox and Etanee. E-tanee aggregators carry out the process of freezing the chilli so that the durability of the chilli becomes longer. The process of freezing vegetables becomes a solution to overcome vegetables that are easily damaged.

It is interesting that the aggregator does not only focus on the marketing sub-system of agricultural products but also does the aggregation in the process of providing inputs for agricultural production. Sikumis.com is one of the online aggregators that focuses on providing input. One of the main problems in developing agribusiness is the policy of providing production facilities, especially seeds, fertilizers, pesticides, and capital (Sisfahyuni, 2008). Meanwhile, quality agricultural production inputs can increase the output of agricultural production (Daniel, 2004). Nowadays farmers are demanded to use modern production inputs to be able to increase productivity (Daryanto, 2012). At present, the distribution of inputs and technology to farmers is a challenge for the government. During this time the government program to channel agricultural inputs through farmers' groups.

\section{Aggregator Partner Profiles}

Aggregator partners consist of farmers and input provider companies that spread across various regions, namely, Bogor, Sukabumi, Jakarta, Central Java, East Java, and Medan. In general, the partners of aggregators are vegetable and fruit farmers. The profiles of farmers who partner with the aggregator are presented in Table 3. 
Based on Table 3, the majority of farmers are 30-39 years old while the majority of farmers in Indonesia are over 35 years old. The number of farmers who become aggregator partners is still very small compared to the number of farmers in Indonesia. One obstacle found is that the adoption of information and communication technology from farmers is still low. João and Franklin (2016) revealed that young farmers also tend to have a higher level of education and be able to use the internet in running their business.

Table 3. Farmers partner profiles

\begin{tabular}{lcc}
\hline Category & $\mathrm{N}$ & $\%$ \\
\hline Age & & \\
$<30$ y.o. & 3 & $8.3 \%$ \\
$30-39$ y.o. & 19 & $52.8 \%$ \\
$40-49$ y.o & 9 & $25.0 \%$ \\
$50-59$ y.o & 4 & $11.1 \%$ \\
$>=60$ y.o & 1 & $2.8 \%$ \\
Type of business & & \\
Vegetable farmer & 15 & $41.7 \%$ \\
Fruit farmers & 14 & $38.9 \%$ \\
Input provider & 7 & $19.4 \%$ \\
Classification & & \\
Individual & 20 & $55.6 \%$ \\
Group & 16 & $44.4 \%$ \\
\hline
\end{tabular}

\section{Distribution chain mechanism}

The process of buying and selling directly between producers and end consumers of agricultural products is very rare. In general, farmers sell products resulting from persecution through intermediaries. This is because the quantity of agricultural products produced is relatively small and will consume higher transportation costs. Aggregator partner farmers market their agricultural products through aggregators, collectors, and directly to end consumers.

Farmer partners benefit greatly from having an online aggregator in the form of a reasonable price and the certainty of absorbing agricultural products. Access to digital technology can offer tangible benefits to smallholders and other rural businesses by providing links to suppliers, utilizing a professional workforce, building strategic partnerships, accessing support services such as training, finance, and legal services and most importantly reaching out to markets and customers (Nikola et al. 2019). At present, the quantity of demand from online aggregators is still relatively small, while the demand from collectors is relatively large so that the role of collectors is still quite large for the process of distributing farmers' products. Figure 2 shows the flow of agricultural products from farmers up to end customers.

In addition, some farmers also try to market their agricultural products directly. Directly marketing to the end consumer is attractive to farmers because the selling price is quite high. However, the amount of these direct sales is relatively small, namely consumers who are in the business location of farmers, so that the quantity of agricultural products absorbed by these direct consumers is relatively very small.

As the alternative marketing channel, it shows that the aggregator is an alternative that provides a better impact compared to other alternatives. Aggregators offer e-commerce as a revolution in agriculture through virtual/online market development that is not limited by time and place in the process of offering or purchasing agricultural products (Blandford and Fulponi, 1997). In a virtual market, a small business scale is not an obstacle. The internet is equalized by providing sales tools to novice businesses to compete effectively with businesses that are already rooted (Cozart, 1998). Sanchez (2000) and Little (2000) stated that farmers begin to turn to the internet to buy goods and services, cut deals, attend auctions, increase sales and reduce costs. The internet gives farmers a way to cut through the long layers of intermediaries which add substantial increases at each level (Doluschitz and Pape, 2001).

The purpose of marketing is to bridge what producers and consumers want in completing the production process (Asmarantaka et al. 2017). Vegetables are homogeneous products where there are many vegetable sellers and buyers. Vegetable commodities also have their market prices that cannot be influenced either by the seller or by the buyer. This shows that the vegetable market is approaching a perfectly competitive market, only that the conditions in the Indonesian vegetable market look like an oligopolistic market where there are a handful of players who influence price-fixing, namely intermediaries (middlemen, collectors, dealers, and other intermediaries). In this case, the vegetable commodity-based online aggregator plays a role in providing a strong sales information system so that producers can dynamically set prices for their products to reflect actual demand or it can be said the aggregator plays a role in perfectly competitive markets (Lambert, 2012). 


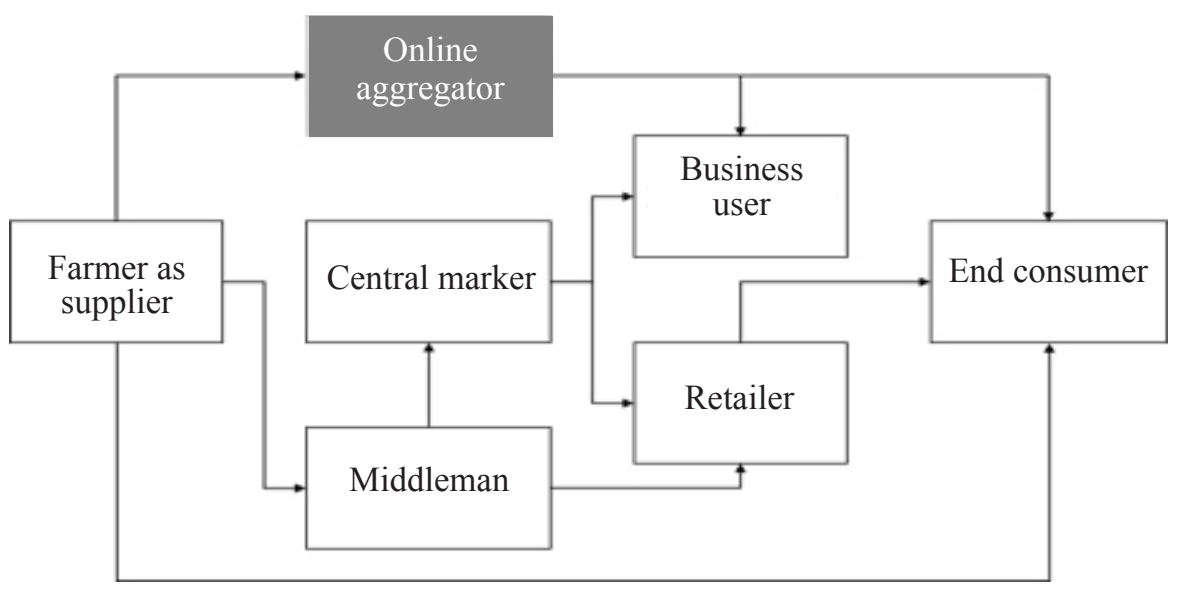

Figure 2. Flow of online-based aggregator business products in agriculture

Refers to aggregator business activities, one of which is channelling agricultural input products. In addition to marketing agricultural products, aggregators also play a role in marketing agricultural input products for farmers. The distribution channel of agricultural input products can be seen in Figure 3.

Aggregators are modern actors who can use information technology (internet) to aggregate agricultural production inputs and distribute them to farmers. Providing agricultural inputs is closely related to marketing agricultural inputs which are generally in the form of seeds, fertilizers, and agricultural equipment. Farmers have easier access to agricultural input sources such as the distribution of fertilizers online. Lasindrang and Fauzi (2018) revealed that imported fertilizers are easier to find because products are sold online, using online store facilities, while local fertilizer producers still adhere to the types of offline distribution that spend more time compared to online distribution. Before the online aggregator, farmers' access to production inputs was limited to retailers in the area closest to the business location. Likewise, input provider companies are very inefficient if they directly sell their products to farmers.

Online aggregators of input providers try to provide information and educate farmers about agricultural machine tools, superior seeds, and fertilizers and provide agricultural inputs at the best prices because these aggregators directly obtain these products/ inputs directly from their suppliers/suppliers. This helps farmers to utilize production inputs effectively and efficiently following the provisions to get optimal production in the production of their farms. Farmers can obtain information related to production inputs in terms of price, quality, and quantity not only from local input products but also from abroad.

\section{Impact on farmers}

The utilization of information technology including information systems in the agricultural sector can increase farmers' incomes (Galtier et al. 2014; Lee and Suzuki 2015; Delima et al. 2016). In the process of marketing agricultural products, the aggregator through applications, websites, and utilizing the internet network can provide price information on agricultural products. It is more transparent and accessible to anyone to find out the information. Thus, this can replace the functions of middlemen or other intermediary traders (collectors) due to consumers' ignorance of product and price information from the first producer level (farmers) as well as being a special attraction for consumers to find out the price level directly from farmers.

Information management by the aggregator provides a variety of benefits for farmers. Farmer partners benefit greatly from having an online aggregator in the form of a reasonable price and the certainty of absorbing agricultural products. The price information is available on the application or website so that everyone can access it.

The results of the paired sample t-test analysis for 15 aggregator partner farmers are presented in Table 4 . The result showed that there was a difference between the selling price to the aggregator and the non-aggregator, this can be seen from the sig value ( 2 tailed) $0.000<0.05$, the descriptive data could be seen on the average selling price. The average selling price of partner farmers to the online aggregator was $\mathrm{Rp} 15,667$, while the average selling price of partner farmers to non-aggregators was Rp 8,723. 


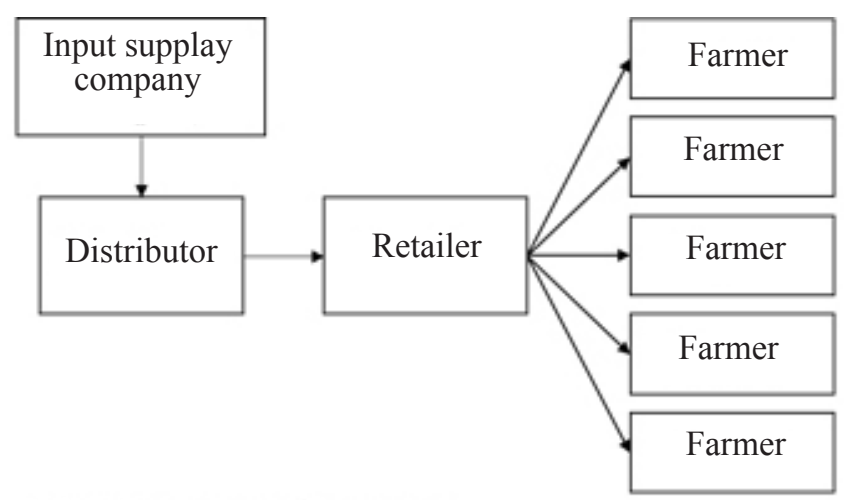

Before there was an online aggregator

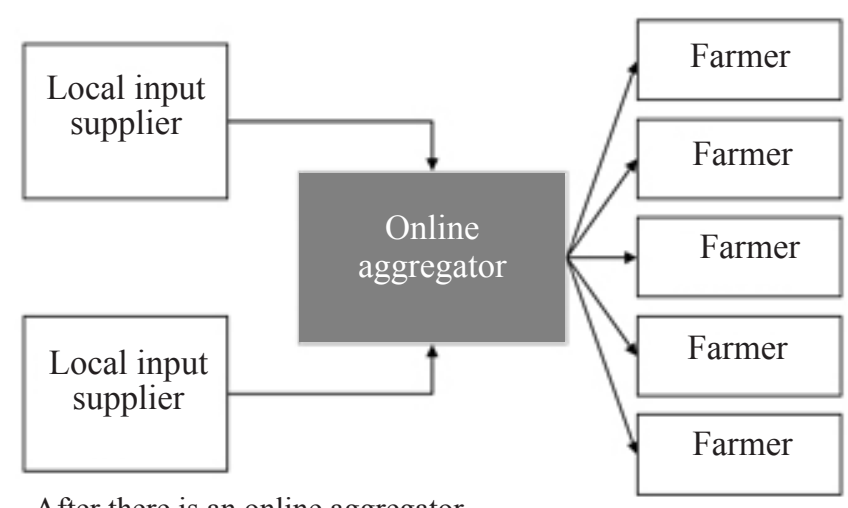

After there is an online aggregator

Figure 3. Input distribution flow

Table 4. Paired Sample T-Test Result

\begin{tabular}{|c|c|c|c|c|c|c|c|c|}
\hline \multirow{3}{*}{ Pair 1} & \multirow{2}{*}{\multicolumn{2}{|c|}{$\frac{\text { Mean }}{\mathrm{A}}$}} & $\mathrm{N}$ & \multicolumn{2}{|c|}{ Std. Deviation } & \multicolumn{3}{|l|}{ Std. Error Mean } \\
\hline & & & 15766.6667 & \multicolumn{2}{|c|}{15} & 6562.51984 & \multicolumn{2}{|c|}{1694.43534} \\
\hline & & & 8273.3333 & \multicolumn{2}{|c|}{15} & 3265.50514 & \multicolumn{2}{|c|}{843.14980} \\
\hline \multicolumn{9}{|c|}{ Paired Samples Test } \\
\hline & \multicolumn{5}{|c|}{ Paired Differences } & \multirow{3}{*}{$\mathrm{t}$} & \multirow{3}{*}{\multicolumn{2}{|c|}{$\begin{array}{c}\text { Sig. } \\
(2 \text {-tailed })\end{array}$}} \\
\hline & \multirow[t]{2}{*}{ Mean } & \multirow[t]{2}{*}{$\begin{array}{c}\text { Std. } \\
\text { Deviation }\end{array}$} & \multirow[t]{2}{*}{$\begin{array}{c}\text { Std. } \\
\text { Error Mean }\end{array}$} & \multicolumn{2}{|c|}{$\begin{array}{l}95 \% \text { Confidence Interval of } \\
\text { the Difference }\end{array}$} & & & \\
\hline & & & & Lower & Upper & & & \\
\hline P 1 A - NA & 7493.3333 & 3443.51703 & 889.11227 & 5586.37717 & 9400.28950 & 8.428 & 14 & .000 \\
\hline
\end{tabular}

Based on the analysis, it can be seen that the existence of the aggregator is able to offer higher price products. However, currently, only a small portion of the volume sold to online aggregators. This is because the quantity of requests from online aggregators is relatively small. Non-online aggregator offers relatively lower prices. The reason farmers continue to sell to non-online aggregators is because farmers' goods are received without being limited by quantity.

In addition, the advantages of online aggregators are more transparent about the selling price of their products to consumers, because both farmers and consumers can directly access the quantity and price of products on smartphone applications or on the website. Other costs such as transportation costs are borne by the aggregator. This is certainly very beneficial for farmers as a solution to the problems they face.

\section{Managerial Implications}

This study found out that aggregator business in agriculture was able to shorter the distribution chain. This implies the efficiency in distribution, leading to efficiency in marketing margin. The emergence of aggregator business in agriculture provides the choice for farmers to sell their products. In addition, the selling price of agricultural products received by farmers through aggregator business was higher than through conventional ones. Thus, there are two managerial implications from this study, i.e. the aggregator business and farmer sides. Firstly, farmers can be opened to the new choice of the distribution chain. They can learn to comply with the requirements of joining the aggregator business in terms of products as well as learn the use of ICT technology in which the aggregator business commonly uses applications. Through compliance with the product requirements of aggregators, farmers can sell their products continuously as well as increasing their sales. Secondly, the aggregator business can provide supervision for farmers who join as partner farmers in terms of ICT technology usage as well as agricultural technical practices. If farmers can comply with the product requirements, the aggregator will be able to increase buying products from partner farmers. By increasing the level of farmer adoption of the services provided by the aggregator, more farmers will be able to join and increase their income. 


\section{CONCLUSIONS AND RECOMMENDATIONS}

\section{Conclusions}

Technology information has a great impact on business, including the supply chain. Aggregator business has emerged by using the internet in the form of applications or websites. Aggregator business may vary from upstream of input supply through downstream of processing or marketing in which the majority is in the marketing. The distribution chain through the aggregator business was shorter compared to conventional in which farmers had specific contracts or agreements with the aggregator business. The impact on farmers who join the aggregator business distribution chain is receiving higher prices, leading to increase farmers' income, transparency in prices where farmers know the selling prices at the consumer level, and farmers know consumer preferences for the products. It is expected that farmers will be able to produce better agricultural produces according to consumer preferences as well as to increase farmers' income.

\section{Recommendations}

Based on the results of this research, farmers would receive a higher price by selling their products to online aggregators. By receiving the higher price, farmers would gain higher income. However, there is a limitation of this research due to the limited number of samples. Therefore, in subsequent studies, a larger number of samples is needed to obtain generalization of the results.

\section{REFERENCES}

Asmarantaka RW, Atmakusuma J, Muflikh YN, Rosiana N. 2018. Konsep pemasaran agribisnis: pendekatan ekonomi dan manajemen. Jurnal Agribisnis Indonesia 5(2): 151-172. https://doi. org/10.29244/jai.2017.5.2.151-172.

Blandford B, Fulponi L. 1997. Electronic markets in the agro-food sector. OECD Observer 208:20-24.

[BPS] Badan Pusat Statistik. 2017. Harga bahan pangan di tingkat produsen pedesaan. http://www.bps. go.id. [10 Jun 2018].

Cozart T. 1998. Ag marketing on the Internet. Successful Farming:1-40.

Daniel M. 2004. Pengantar Ekonomi Pertanian. Jakarta: Bumi Aksara.
Daryanto A. 2012. Memposisikan secara tepat pembangunan pertanian dalam perspektif pembangunan nasional. https://pse.litbang. pertanian.go.id. [20 Feb 2019].

Delima R, Santoso HB, Purwadi J. 2016. Kajian aplikasi pertanian yang dikembangkan di beberapa negara Asia dan Afrika. http://journal.uii.ac.id. [20 Feb 2019].

Dillemuth A, Hodgson K. 2016. Food aggregation, processing, and distribution. In Kimberley Hodgson and Samina Raja (Series Editors), Planning \& Policy Briefs. Growing Food Connections.https://growingfoodconnections. org[3 Jul 2019].

[FAO] Food and Agriculture Organization of The United Nation. 2012. Global food losses and food waste - Extent, causes and prevention. Rome: FAO

Fikri A, Nurmalina R, Najib M, Simanjuntak M. 2019. The effect of reputation on online repurchase intention of fruits/vegetables in Indonesia with emotional and perceived risk as antecedent: based on the stimulus-organism-response model. Jurnal Manajemen \& Agribisnis 16(2):111-122. https://doi.org/10.17358/jma.16.2.111.

Galtier F, Benz HD, Subervie J, Egg J. 2014. Agricultural market information sistems in developing countries: New models, new impacts. Cahiers Agricultures 23:232-244. https://doi. org/10.1684/agr.2014.0716.

João RF, Franklin GM. 2016. Farmer-entrepreneurs, agricultural innovation, and explosive research and development cycles. Administrative Science 6(13):1-11. https://doi.org/10.3390/ admsci6040013.

Lambert Q. 2012. Business models for an aggregator [tesis]. Information Management \& Computer Security.

Larson AM. 2014. Land market integration, structural change, and smallholder farming in Zambia [disertasi]. Minnesota: University of Minnesota.

Lasindrang LFY, Fauzi ADH. 2018. Hubungan distribusi terhadap penjualan (studi pada distribusi pupuk npk non subsidi area pemasaran Kalimantan di PT. Pupuk Kalimantan Timur). Jurnal Administrasi Bisnis 54(1):197-206.

Lee G, Suzuki A. 2015. Evaluating the impact of market information sistem on coffee producers': Revenues and profits in Ethiopia. https:// editorialexpress.com. [25 Jan 2019].

Lembong T. 2016. Konsep dasar agregator. Jakarta: Info Perdagangan Dalam Negeri. 
Little D. 2000. Old McDonald has a website: online exchanges for farmers are cutting costs for seed, feed, and chemicals while boosting prices for products. Business Week 268:82-89.

Mejía G, García-Díazc C. 2018. Market-level effects of firm-level adaptation and intermediation in networked markets of fresh foods: A case study in Colombia. Agricultural Systems 160:132-142. https://doi.org/10.1016/j.agsy.2017.06.003.

Moghaddan G, Moballeghi M. 2007. The importance of agregators for libraries in the digital era. Interlending \& Document Supply 35(4): 222 225. doi: 10.1108/02641610710837536.

Nayak J. 2016. Role of information and communication technology in agricultural marketing in india. Anveshana 6(1):82-96. https://doi.org/10.23872/ aj/2016/v6/i1/129254.

Nikola M, Trendov, Samuel V, Meng Z. 2019. Digital Technologies in Agriculture and Rural Areas. Rome: Briefing Paper Food and Agriculture Organization of the United Nations Rome.

Nurchayati H. 2014. Pola distribusi buah lokal dan buah impor: strudi kasus pada pedagang buah di Kota Semarang. Research Methods an Organizational Studies:40-50.
Ranjan R. 2017. Challenges to farm produce marketing: A model of bargaining between farmers and middlemen under risk. Journal of Agricultural and Resource Economics 42(3):386-405.

Sanchez S. 2000. E-commerce profile: Farmbid.com: Creating a one stop shop. Agri Marketing.

Santoso PB, Darwanto. 2015. Strategi penguatan kelompok tani dengan penguatan kelembagaan. Jurnal Ekonomi Pembangunan 16(1):33-45.

Shankar T, Singh KM, Dwiwedi S. 2017. An analysis on problems of vegetables marketing in farmers market of Jharkhand. Economic Affairs 62(1):175-183. https://doi.org/10.5958/09764666.2017.00041.9.

Shaik N.Meera, Jhamtani A, RaoDUM. 2004. Information and communication technology in agricultural development: a comparative analysis of three projects from India. AgREN Network Paper No.135.

Sisfahyuni, Ludin, Taufik. 2008. Komposisi industri yang membangun sektor pertanian Sulawesi Tengah. Jurnal Agroland 15(4): 316-322.

Tapsavi SK. 2009. Uttarakhand state cooperative federation: can it help the horticulture farmers? The JournalofBusiness Perspective 13(21):63-64. https://doi.org/10.1177/097226290901300207. 